\title{
Trading stocks following sharp movements in the USDX, GBP/USD, and USD/CNY
}

\author{
Yensen $\mathrm{Ni}^{1}$, Min-Yuh Day ${ }^{2}$ and Paoyu Huang ${ }^{3^{*}}$
}

\author{
* Correspondence: hpy@scu.edu.tw \\ ${ }^{3}$ Department of International \\ Business, Soochow University, \\ No.56, Sec. 1, Kueiyang St., Taipei \\ City 100 , Taiwan \\ Full list of author information is \\ available at the end of the article
}

\begin{abstract}
We hypothesized that sharp movement in the USDX, GBP/USD, and USD/CNY might result in stock market fluctuations owing to heightened investors' sentiments. The subsequent performance of trading stocks right after such sharp movements in exchange rates is seldom explored in existing studies. We examined the historical data of the constituent stocks of the DJ 30, FTSE 100, and SSE 50 indexes and found that the share prices were more volatile after sharp movements in the CNY, even though the currency is less volatile because of China's exchange rate policy. However, for the USD and GBP, share prices of the DJ 30 and FTSE 100, respectively, rose after sharp appreciation and depreciation of the currencies.
\end{abstract}

Keywords: Investing strategies, Exchange rates, Investors' sentiments

\section{Introduction}

Share prices are difficult to predict since prices always reflect relevant information according to the efficient market hypothesis (Fama, 1965, 1991, 1998). However, this viewpoint is challenged by the overreaction hypothesis (Debondt \& Thaler, 1985, 1987), which supposes that (i) investors may overreact to the available and private information released owing to excessive self-confidence (Chuang \& Lee, 2006; Daniel, Hirshleifer, \& Subrahmanyam, 1998), (ii) herd behaviors result in chasing rising or falling prices (Chalmers, Kaul, \& Phillips, 2013; Mendel \& Shleifer, 2012), and (iii) investors' sentiments and behavioral pscyhology have an impact on price movements ( $\mathrm{Da}$, Engelberg, \& Gao, 2015; Dergiades, 2012; Huang et al., 2014; Huang \& Ni, 2017; Kumar, Page, \& Spalt, 2013).

In this study, in divergence from the commonly explored causal relationship between share prices and exchange rates (Ajayi \& Mougouė, 1996; Basher, Haug, \& Sadorsky, 2012; Dornbusch, 1987; Grammig, Melvin, \& Schlag, 2005; Pan et al., 2007a, b), we mainly investigated whether market participants are able to beat the market. Instead of employing time-series models, we used the standard event study approach to examine whether investors are able to gain abnormal returns (ARs) and cumulative abnormal returns (CARs). Specifically, we explored whether market participants outperform the 
markets right after a sharp rise or fall in exchange rates represented by USDX, GBP/ USD, and USD/CNY. ${ }^{1}$

We included the constituent stocks of the Dow Jones Industrial Average 30 index (D) 30), Financial Times Stock Exchange 100 index (FTSE 100), and the Shanghai Stock Exchange 50 index (SSE 50) as our samples, since investors are able to buy the constituent stocks of these stock indexes instead of index spots. We then explored whether our results are different among these representative stock markets.

We define sharp rises or falls in exchange rates (i.e., the rises or falls in exchange rates over $0.25 \%, 0.5 \%, 0.75 \%$, and $1 \%$ ) as our events. The events explored in this study are different from those explored in other studies, such as the declaration of dividend yield (Charest, 1978; Firth, 1996), merger or acquisition (Barney, 1988; Hackbarth \& Morellec, 2008), and stock repurchase (Lie, 2005; Netter \& Mitchell, 1989), among others. That is, we tested whether investors are able to beat the market following sharp movements in the exchange rate instead of these other events tested in previous studies. Our study expands the applications of the event study approach.

The contributions of this study are as follows: first, we explored whether a sharp rise (fall) in exchange rates provides valuable and unrevealed information to market participants for trading our selected sample stocks, which is rarely examined in the literature. Second, we compared the profitability of trading the constituent stocks of the DJ 30, FTSE 100, and SSE 50, as these three stock markets are representative markets. Third, this study links the occurrence of sharp rises (falls) in exchange rates with market efficiency and inefficiency, overreaction, investors' sentiments, and herd behaviors, which is not adequately studied in the existing literature.

We found that share prices rose when the USD and GBP depreciate or appreciate sharply, and positive CARs are observed without exception. Share prices were more volatile following sharp movements in the CNY, especially with sharp depreciation. Our results are beneficial for investors who trade these constituent stocks around occurrences of sharp currency movements. We argue that these stock markets might be inefficient, as sharp movements in exchange rates result in stock price overreaction possibly because of investors' heightened sentiments and/or herd behaviors.

The rest of the study is organized as follows: we survey the relevant literature in the second section. The third section describes the study design and data. The fourth section presents the empirical results. The concluding remarks and recommendations are provided in the final section.

\section{Literature review}

We reviewed the relevant literature related to market efficiency, market inefficiency, herd behaviors, and positive feedback trading. Given that whether investors are able to beat the market around sharp movements in exchange rates is related to investing strategies, we also reviewed the relevant literature related to investing strategies and the relationship between exchange rates and stock markets.

With regard to market efficiency and inefficiency, we found no consistent conclusion documented in the literature (Debondt \& Thaler, 1985, 1987; Fama, 1965, 1991;

${ }^{1}$ USDX: US Dollar (USD) to a basket of currenciesGBP/USD: Great British Pound (GBP) to USD exchange rateUSD/CNY: USD to Chinese Yuan (CNY) exchange rate 
Kahneman \& Tversky, 1979; Malkiel \& Fama, 1970; Nguyen, 2016). Technical trading rules that are widely applied in the real world seem to challenge the market efficiency hypothesis (Bessembinder \& Chan, 1995; Brock, Lakonishok, \& Lebaron, 1992). Schwert (2003) argued that there exist anomalies that seem to be inconsistent with the market efficiency hypothesis, indicating that market inefficiency likely exists in the stock markets.

Herd behaviors, such as simultaneous buying or selling of the same stocks by many investors, have been reported (Balcilar, Demirer, \& Hammoudeh, 2013; Economou, Kostakis, \& Philippas, 2011; Frey, Herbst, \& Walter, 2014; Grinblatt, Titman, \& Wermers, 1995; Lakonishok, Shleifer, \& Vishny, 1992; Ni, Liao, \& Huang, 2015; Nofsinger \& Sias, 1999; Wu, Huang, \& Ni, 2017a), which indicates that momentum strategies may be useful in trading. Herd behaviors are often observed in trading by institutions, such as mutual and pension funds (Brown, Wei, \& Wermers, 2013; Dennis \& Strickland, 2002; Kremer \& Nautz, 2013; Raddatz \& Schmukler, 2013; Sias, 2004; Zheng et al., 2015). Griffin, Harris, and Topaloglu (2003) found that strong contemporaneous daily patterns can be largely explained by net institutional trading following the past intraday excess stock returns.

Positive feedback trading refers to buying past winners and selling past losers, in which investors are likely to chase rising (falling) prices, which, in turn, will result in share prices rising (falling) continuously. Regarding positive feedback trading, Nofsinger and Sias (1999) showed that institutional investors engage in more positive feedback trades than individual investors. Koutmos and Saidi (2001) also reported evidence of positive feedback trading and selling/buying during market declines/advances in developed stock markets. Kurov (2008) showed that traders in the index futures markets are positive feedback traders. Dennis and Strickland (2002) also found positive feedback trading by some institutions, particularly mutual and pension funds. Wang (2002) found that large hedgers behave like positive feedback traders, but small traders are liquidity traders. Antoniou, Koutmos, and Pericli (2005) supported the view that futures markets help stabilize the underlying spot markets by reducing the effect of feedback traders, thereby attracting more rational investors who make the markets more informationally efficient and providing investors with superior ways of managing risk.

Regarding momentum strategies, Menkhoff et al. (2012) reported a significant crosssectional spread in excess returns between past winner and loser currencies in the foreign exchange market. Ni, Liao, and Huang (2015) found that investors might adopt momentum strategies in trading stocks in the Chinese stock exchanges because of over-optimism that likely exists because individual investors account for $80 \%$ of the trading volume. With respect to contrarian strategies, De Haan and Kakes (2011) pointed out that several institutional investors in the Netherlands, such as pension funds and life and non-life insurers, tended to be contrarian traders. Malin and Bornholt (2013) found that the reversal of long-term returns in international equity markets may be stronger and more persistent than is generally understood, indicating that contrarian strategies might be appropriate in long-run investments.

Concerning the relationship between exchange rates and stock markets, Aggarwal (1981) found that US stock prices and the dollar were positively correlated. Donnelly and Sheehy (1996) documented a significant contemporaneous relation between exchange rates and the market values of large UK exporters. Bahmani-Oskooee and 
Sohrabian (1992) showed that there is bidirectional causality between the S\&P 500 stock index and the effective exchange rates of the dollar. Chiang and Yang (2003) found that stock returns and currency values were positively related in nine Asian markets.

However, Ajayi et al. (1999) showed unidirectional causality from the stock markets to the currency markets for advanced economies but not for emerging economies. Ramasamy and Yeung (2002) found that the results are inconsistent for bivariate causality between stock prices and exchange rates. Bartov and Bodnar (1994) did not find a significant contemporaneous relation between USD movements and stock returns for US firms. Griffin and Stulz (2001) found that weak exchange rate shocks had negligible impacts on the performance of industries in six industrialized countries.

The relationship between exchange rates and stock markets has been explored in numerous studies (Aggarwal, 1981; Ajayi et al., 1999; Bahmani-Oskooee \& Sohrabian, 1992; Bahmani-Oskooee \& Saha, 2017; Bartov \& Bodnar, 1994; Chiang \& Yang, 2003: Donnelly \& Sheehy, 1996; Hamao et al., 1990; Jorion, 1990; Griffin \& Stulz, 2001; Karolyi, 1995; King \& Wadhwani, 1990; Lin, 2011; Lin et al., 1994; Ramasamy \& Yeung, 2002; Schwert, 1990; Theodosiou \& Lee, 1993). The market efficiency hypothesis has been challenged by researchers (Chuang \& Lee, 2006; Daniel et al., 1998) who claim that overreactions, herd behaviors, positive feedback, investors' sentiments, and other factors oppose the hypothesis (Antoniou, Koutmos, \& Pericli, 2005; Baker \& Wurgler, 2006; Chiang \& Zheng, 2010; Debondt \& Thaler, 1985, 1987; Kurov, 2008; Liao, Huang, \& Wu, 2011; Nofsinger \& Sias, 1999; Scharfstein \& Stein, 1990; Schmeling, 2009).

We argue that currency appreciation (depreciation) results from capital inflows (outflows) that result in rising (falling) share prices in accordance with the viewpoints about the behaviors and impacts of the capital account (Calvo, Leiderman, \& Reinhart, 1993, 1996; Wu, Huang, \& Ni, 2017b). However, currency depreciation (appreciation) might also increase exports (imports) by enhancing (reducing) the competitiveness of domestic products, resulting in rising (falling) share prices based on the viewpoints about the current account (Chinn, 2006; Corsetti et al. 2000; Fang, Lai, \& Miller, 2006; Gruber, \& Kamin, 2007; Zia \& Mahmood, 2013). ${ }^{2}$

Aside from the above mechanism, the short-term stock price performance (CARs) might be affected by the interpretation of individual investors and institutional market participants. In addition, short-term share price performance is likely affected by the heightening of investors' sentiments due to sharp rises (falls) in exchange rates (Heiden, Klein, \& Zwergel, 2013; Rehman, 2013), which might result in herd behaviors as per the theories of behavioral finance (Bekiros et al. 2017; Ramiah, Xu, \& Moosa, 2015). Accordingly, we argue that investors' sentiments would be another mechanism. We regard that share prices are likely affected by not only economic factors but also psychological factors. In sum, we examined the subsequent performance of trading stocks immediately after sharp movements in the USDX, GBP/USD, and USD/CNY. This relationship is insufficiently explored in the existing literature.

${ }^{2}$ The current and capital accounts represent two halves of a nation's balance of payments. The current account represents a country's net income over a period of time, while the capital account records the net change of assets and liabilities during a particular year. 


\section{Study design and data \\ Design of this study}

We argue that a sharp rise (fall) in exchange rates conveys valuable information. We first classified sharp rises (falls) in exchange rates according to the thresholds of $0.25 \%$, $0.5 \%, 0.75 \%$, and $1 \%$ as our events. We then measured the one-, two-, three-, four-, and five-day cumulative abnormal returns around the occurrence of these events. We used the standard event study approach to examine stock price movements following these events.

We defined day 0 as the day when the above-mentioned events occurred. Abnormal return was defined as the difference between the actual return and the expected return generated by the market model. We used three indices, namely DJ 30, FTSE 100, and SSE 50, as the proxies for market returns and then estimated the parameters of the market model by using data over the period from -155 to -6 days (i.e., 150 days) before day 0 .

Cumulative abnormal returns at $\mathrm{t}$ days $(\mathrm{CAR}(\mathrm{t}))$ are the cumulative abnormal returns from AR (1) to AR ( $t$ ). Given that investors might hold stocks for a short period, we measured one-, two-, three-, four-, and five-day CARs considering them as short windows in line with the literature (Ahern, 2009; Chopra, Lakonishok, \& Ritter, 1992; Marshall, Young, \& Rose, 2006). Finally, we tested whether these CARs are statistically different from zero based on their $\mathrm{t}$ statistics.

We present the empirical results for the constituent stocks of the DJ 30, FTSE 100, and SSE 50 in Columns 1-3 of Tables 3 and 4 in Section 4. The CAR results associated with the sharp rises and falls in exchange rates are shown in Panels A-D of Tables 3 and 4, respectively.

\section{Data}

We used the daily data for USDX, GBP/USD, and USD/CNY and the constituent stocks of the DJ 30, FTSE 100, and SSE 50 from Datastream (a financial database) from 2006 to 2015. Figure 1 shows an upward trend in the US stock market after the 2008 stock market crisis, a stable trend in the UK stock market, and two peaks, in 2007 and 2015,

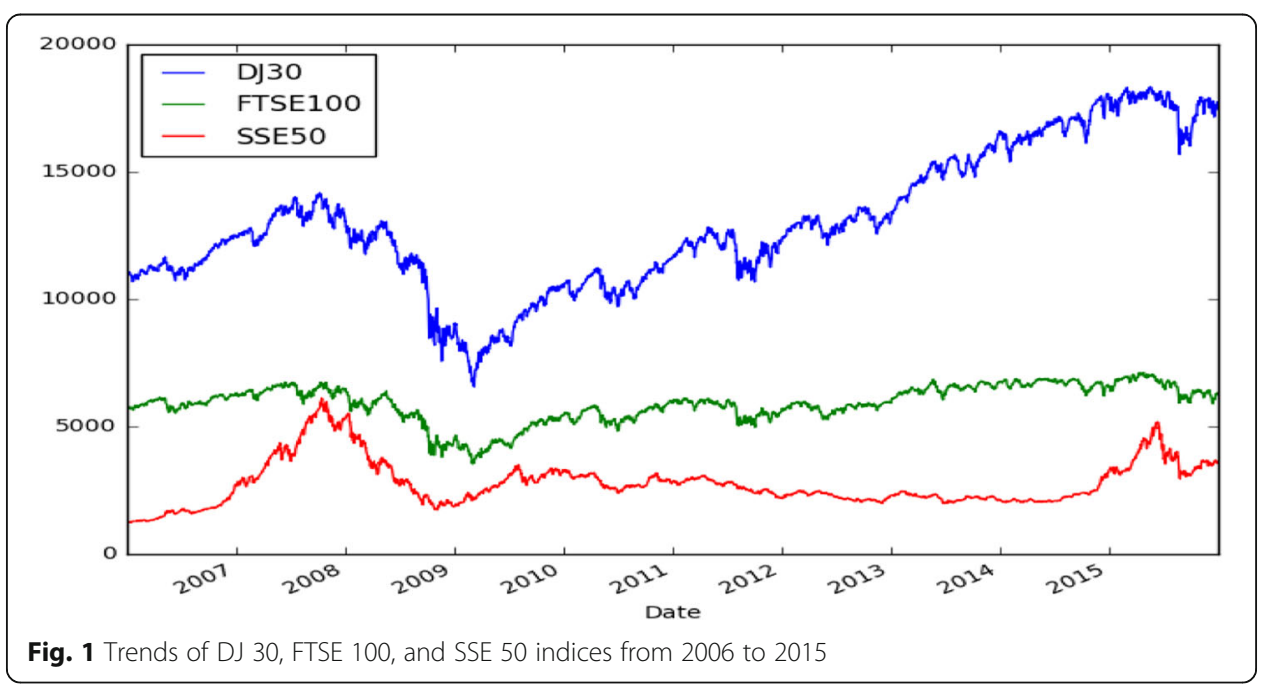


for the China stock market. Figure 1 indicates that the China stock market is more volatile than the US and UK stock markets; however, the volatility of USD/CNY seems less than that of USDX and GBP/USD, as shown in Fig. 2.

Table 1 lists the means, medians, standard deviations, minima, and maxima for the currencies and representative indices for data over the period of 2006-2015.

Panel A of Table 1 shows that the ranges of these stock indices are rather wide as revealed by their minima and maxima, especially for the China stock index. The minima may be a result of the global financial crisis in 2008. USD/CNY is less volatile than USDX and GBP/USD, as shown in Panel C of Table 1. These statistics suggest that the China stock market is more volatile than the other two markets, whereas the currency volatility of the CNY is less than the USD and GBP.

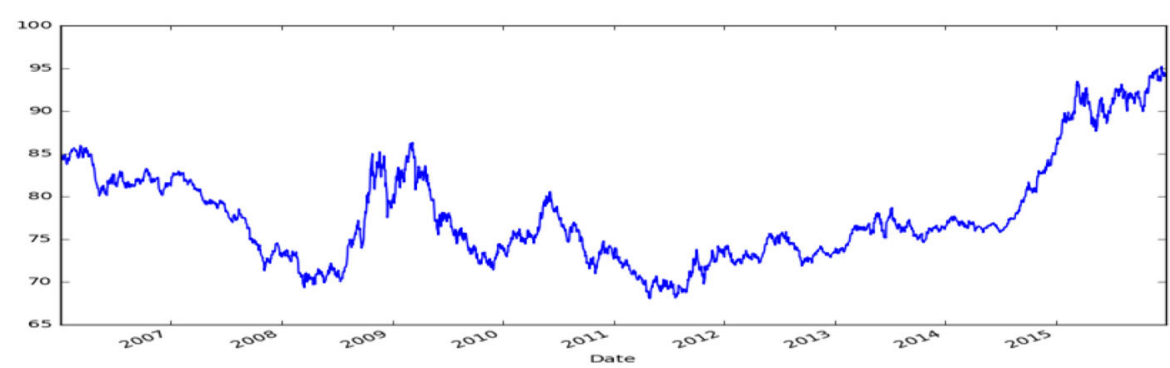

Trends of US Dollar Index from 2006 to 2015

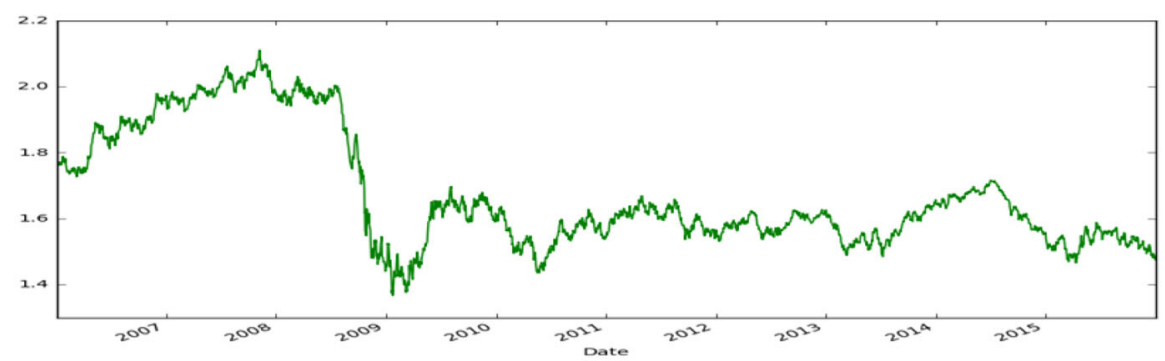

Trends of GBP/USD from 2006 to 2015

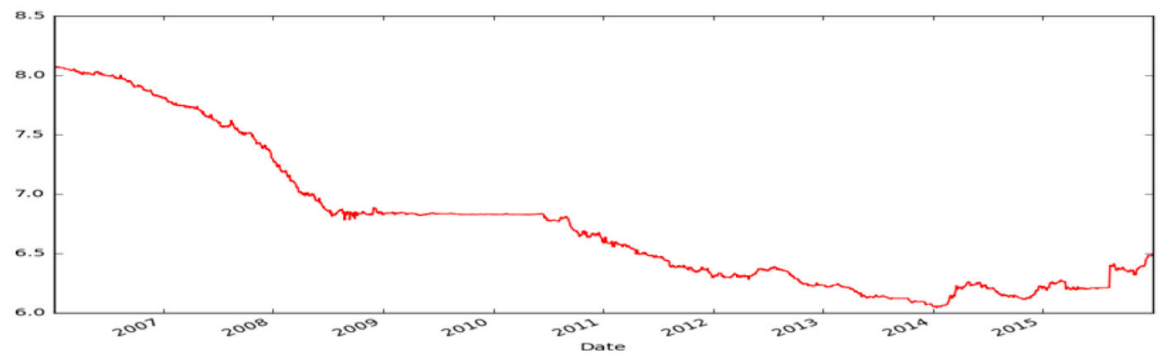

Trends of USD/CNY from 2006 to 2015

Fig. 2 Trends of three currencies from 2006 to 2015 
Table 1 Summary statistics. This table reports the means, standard deviations, maxima, and minima for USDX, GEP/USD, and USD/CNY as well as DJ30, FTSE100, and SSE50 indices over the data period 2006-2015

\begin{tabular}{|c|c|c|c|c|c|}
\hline Variable & Obs. & Mean & Std. Dev. & Min & Max \\
\hline \multicolumn{6}{|l|}{ Panel A: stock index levels } \\
\hline DJ 30 index & 2517 & $12,968.21$ & 2722.62 & 6547.05 & $18,312.39$ \\
\hline FTSE 100 index & 2594 & 5885.81 & 719.88 & 3512.10 & 7104.00 \\
\hline SSE 50 index & 2481 & 2740.83 & 903.63 & 1161.06 & 6092.06 \\
\hline \multicolumn{6}{|l|}{ Panel B: stock index returns } \\
\hline DJ 30 index returns & 2517 & $0.026 \%$ & $1.201 \%$ & $-7.873 \%$ & $11.080 \%$ \\
\hline FTSE 100 index returns & 2594 & $0.012 \%$ & $1.251 \%$ & $-8.848 \%$ & $9.839 \%$ \\
\hline SSE 50 index returns & 2481 & $0.060 \%$ & $1.788 \%$ & $-8.841 \%$ & $9.455 \%$ \\
\hline \multicolumn{6}{|l|}{ Panel C: currencies } \\
\hline USDX & 2509 & 77.79 & 6.00 & 68.00 & 95.21 \\
\hline GBP/USD & 2513 & 1.67 & 0.17 & 1.37 & 2.11 \\
\hline USD/CNY & 2513 & 6.75 & 0.60 & 6.04 & 8.07 \\
\hline \multicolumn{6}{|l|}{ Panel D: currency changes } \\
\hline$\triangle U S D X$ & 2509 & $0.005 \%$ & $0.483 \%$ & $-4.024 \%$ & $2.179 \%$ \\
\hline$\triangle \mathrm{GBP} / \mathrm{USD}$ & 2513 & $-0.004 \%$ & $0.617 \%$ & $-4.845 \%$ & $4.535 \%$ \\
\hline$\triangle \mathrm{USD} / \mathrm{CNY}$ & 2513 & $-0.009 \%$ & $0.122 \%$ & $-0.993 \%$ & $1.833 \%$ \\
\hline
\end{tabular}

Note: US Dollar Index (USDX) is measured by a basket of currencies USD/CNY: US Dollar (USD) to Chinese Yuan (CNY) exchange rate GEP/USD: Great British Pound (GBP) to US Dollar (USD) exchange rate $\triangle \mathrm{USDX}=(\mathrm{USDX}(\mathrm{t}) / \mathrm{USDX}(\mathrm{t}-1))-1$

$\triangle \mathrm{GBP} / \mathrm{USD}=(\mathrm{GBP} / \mathrm{USD}(\mathrm{t}) / \mathrm{GBP} / \mathrm{USD}(\mathrm{t}-1))-1$

$\triangle \mathrm{USD} / \mathrm{CNY}=(\mathrm{USD} / \mathrm{CNY}(\mathrm{t}) / \mathrm{USD} / \mathrm{CNY}(\mathrm{t}-1))-1$

The results indicate that the stock market in China seems to be sensitive to sharp currency movements even though exchange rate movements are managed by the government. We argue that these statistics might contain valuable and unreleased information for stock trading.

We investigated the association between currency movements and stock market performance and examined whether investors are able to beat the markets in the trading of the constituent stocks of the DJ 30, FTSE 100, and SSE 50 right after a sharp rise (fall) in the USDX, GBP/USD, and USD/CNY. We defined our events as the rises (falls) in exchange rates of more than $0.25 \%, 0.5 \%, 0.75 \%$, and $1 \%{ }^{3}$ We have listed the numbers of the sharp rise (fall) in exchange rates that occurred for the constituent stocks of these indices over the data period in Table 2.

The samples of the sharp rise in exchange rates for the four thresholds (i.e., over $0.25 \%, 0.5 \%, 0.75 \%$, or $1 \%$ rise) are similar to those of the sharp falls, indicating that the currency appreciation and depreciation shocks occurred similarly over the data period from 2006 to 2015. An over 1\% fall did not occur in the data period for China, which might be a result of the central management of the CNY. Sharp movements in the GBP occurred often in the United Kingdom, which might be related to the share prices and constituent companies of the FTSE 100.

\footnotetext{
${ }^{3}$ Exchange rates rising (falling) more than $0.25 \%, 0.5 \%, 0.75 \%$, and $1 \%$ in a day is an infrequent occurrence in many currency markets. We consider such events as currency shocks in this study.
} 
Table 2 The samples of the sharp rise (fall) in exchange rates. Panel A of Table 2 lists the numbers of the sharp rise in exchange rates (USDX, GBP/USD, and USD/CNY) over $0.25 \%, 0.5 \%, 0.75 \%$, and $1 \%$ for the constituent stocks of DJ 30, FTSE 100, and SSE 50. Panel B of Table 2 lists the numbers of the sharp fall in exchange rates over $0.25 \%, 0.5 \%, 0.75 \%$, and $1 \%$ for the constituent stocks of DJ 30, FTSE 100, and SSE 50

\begin{tabular}{llll}
\hline & DJ30 & FTSE100 & SSE50 \\
\hline Panel A: Various sharp rises in exchange rates & & & \\
Over 0.25\% rise in exchange rates & 19,233 & 55,760 & 1509 \\
Over 0.5\% rise in exchange rates & 8913 & 29,238 & 274 \\
Over 0.75\% rise in exchange rates & 4179 & 14,462 & 175 \\
Over 1\% rise in exchange rates & 1881 & 7905 & 49 \\
Panel B: Various sharp falls in exchange rates & & & 1782 \\
Over 0.25\% fall in exchange rates & 19,002 & 53,130 & 263 \\
Over 0.5\% fall in exchange rates & 8338 & 29,861 & 115 \\
Over 0.75\% fall in exchange rates & 3849 & 15,080 & 0 \\
Over 1\% fall in exchange rates & 1703 & 8231 & \\
\hline
\end{tabular}

\section{Empirical results and analysis}

We measured the one-, two-, three-, four-, and five-day CARs around sharp exchange rate movements. We have presented the CARs and their $t$ values for the constituent stocks of the DJ 30, FTSE 100, and SSE 50 immediately after sharp rises and falls in exchange rates in Tables 3 and 4 , respectively. ${ }^{4}$

\section{Results of sharp rises in exchange rates}

Table 3 shows that most of the CARs are positive for the constituent stocks of the DJ 30 and FTSE 100 for over $0.25 \%, 0.5 \%, 0.75 \%$, and $1 \%$ rises in the exchange rates in a day, especially for CAR (4) and CAR (5). The results indicate that taking long positions might be appropriate for these stocks for four to 5 days after a sharp appreciation of the USD and GBP.

As for the result for China, most of the CARs are negative for the constituent stocks of the SSE 50 for over $0.25 \%, 0.5 \%, 0.75 \%$, and $1 \%$ rises in the exchange rate in a day. Especially, CAR (5) was $-2.04 \%$ and $-5.10 \%$ for over $0.75 \%$ and $1 \%$ rises in the exchange rate in a day, respectively, which are sizeable movements. The results indicate that taking a short position would be appropriate for trading the constituent stocks of the SSE 50 after a sharp depreciation of the CNY.

In summary, the CARs rise after the appreciation of the USD and GBP, whereas the CARs decline after the depreciation of the CNY.

\section{Results of sharp falls in exchange rates}

Table 4 shows that almost all of the CARs are positive for trading the constituent stocks of the DJ 30 and FTSE 100 for over $0.25 \%, 0.5 \%, 0.75 \%$, and $1 \%$ falls in the exchange rate in a day, implying that a contrarian strategy might be appropriate for trading the constituent stocks of the DJ 30 and FTSE 100 following a sharp appreciation of

\footnotetext{
${ }^{4}$ We also split our data into two periods, 2007-2009 and 2009-2015, to assess the contagion effects of the financial crisis and found that the results are almost the same for both periods.
} 
Table 3 CARs of diverse sharp rises in exchange rates. We investigate whether these CARs including 1-, 2-, 3-, 4-, and 5-day CARs would be different from 0 if investors take the long positions in the constituent stocks of DJ 30, FTSE 100, and SSE50 as the sharp rise in exchange rates over $0.25 \%, 0.5 \%, 0.75 \%$, and $1 \%$ in a day. We also present the statistics of t-tests for these CARs. In addition, ${ }^{*}, * *$, and ${ }^{* * *}$ represent $10 \%, 5 \%$, and $1 \%$ significance levels, respectively

\begin{tabular}{|c|c|c|c|c|c|c|c|c|c|}
\hline \multirow{3}{*}{$\begin{array}{l}\text { Holding } \\
\text { days }\end{array}$} & \multicolumn{3}{|l|}{ (1) } & \multicolumn{3}{|l|}{$(2)$} & \multicolumn{3}{|l|}{ (3) } \\
\hline & \multicolumn{3}{|l|}{ DJ30 } & \multicolumn{3}{|l|}{ FTSE100 } & \multicolumn{3}{|l|}{ SSE50 } \\
\hline & Returns & \multicolumn{2}{|l|}{$t$-test } & Returns & \multicolumn{2}{|l|}{ t-test } & Returns & \multicolumn{2}{|l|}{ t-test } \\
\hline \multicolumn{10}{|c|}{ Panel A: Over $0.25 \%$ rise in exchange rates } \\
\hline 1 & $0.04 \%$ & 3.492 & $* * *$ & $0.07 \%$ & 7.013 & $* * *$ & $-0.03 \%$ & -0.479 & \\
\hline 2 & $0.04 \%$ & 2.425 & $* *$ & $0.07 \%$ & 5.418 & $* * *$ & $0.23 \%$ & 2.378 & ** \\
\hline 3 & $0.07 \%$ & 3.476 & $* * *$ & $0.12 \%$ & 7.406 & $* * *$ & $0.10 \%$ & 0.876 & \\
\hline 4 & $0.09 \%$ & 3.870 & $* * *$ & $0.18 \%$ & 9.276 & $* * *$ & $-0.05 \%$ & -0.323 & \\
\hline 5 & $0.16 \%$ & 6.208 & $* * *$ & $0.25 \%$ & 11.829 & $* * *$ & $-0.18 \%$ & -1.094 & \\
\hline \multicolumn{10}{|c|}{ Panel B: Over $0.5 \%$ rise in exchange rates } \\
\hline 1 & $0.07 \%$ & 3.372 & $* * *$ & $0.10 \%$ & 6.678 & $* * *$ & $0.56 \%$ & 4.483 & *** \\
\hline 2 & $0.11 \%$ & 3.897 & $* * *$ & $0.15 \%$ & 7.269 & $* * *$ & $0.90 \%$ & 5.648 & $* * *$ \\
\hline 3 & $0.15 \%$ & 4.468 & $* * *$ & $0.22 \%$ & 8.459 & $* * *$ & $0.57 \%$ & 2.405 & $* *$ \\
\hline 4 & $0.16 \%$ & 4.179 & $* * *$ & $0.36 \%$ & 12.270 & $* * *$ & $-0.30 \%$ & -1.016 & \\
\hline 5 & $0.22 \%$ & 5.482 & $* * *$ & $0.45 \%$ & 13.974 & $* * *$ & $-1.09 \%$ & -3.072 & *** \\
\hline \multicolumn{10}{|c|}{ Panel C: Over $0.75 \%$ rise in exchange rates } \\
\hline 1 & $0.18 \%$ & 4.998 & $* * *$ & $0.10 \%$ & 3.797 & *** & $0.15 \%$ & 1.046 & \\
\hline 2 & $0.18 \%$ & 3.647 & $* * *$ & $0.13 \%$ & 3.848 & $* * *$ & $0.65 \%$ & 3.552 & $* * *$ \\
\hline 3 & $0.21 \%$ & 3.695 & $* * *$ & $0.20 \%$ & 4.767 & $* * *$ & $0.30 \%$ & 0.955 & \\
\hline 4 & $0.27 \%$ & 4.033 & $* * *$ & $0.32 \%$ & 6.830 & $* * *$ & $-0.99 \%$ & -2.486 & $* *$ \\
\hline 5 & $0.34 \%$ & 4.769 & $* * *$ & $0.36 \%$ & 6.958 & $* * *$ & $-2.04 \%$ & -4.079 & *** \\
\hline \multicolumn{10}{|c|}{ Panel D: Over $1 \%$ rise in exchange rates } \\
\hline 1 & $0.33 \%$ & 5.242 & $* * *$ & $0.13 \%$ & 3.421 & $* * *$ & $-0.52 \%$ & -1.731 & * \\
\hline 2 & $0.18 \%$ & 2.225 & $* *$ & $0.26 \%$ & 5.232 & $* * *$ & $-0.14 \%$ & -0.353 & \\
\hline 3 & $0.20 \%$ & 2.172 & $* *$ & $0.35 \%$ & 5.744 & $* * *$ & $-0.39 \%$ & -0.949 & \\
\hline 4 & $0.19 \%$ & 1.696 & * & $0.41 \%$ & 5.894 & $* * *$ & $-1.33 \%$ & -2.348 & $* *$ \\
\hline 5 & $0.43 \%$ & 3.694 & $* * *$ & $0.42 \%$ & 5.861 & $* * *$ & $-5.10 \%$ & -9.548 & $* * *$ \\
\hline
\end{tabular}

the USD and GBP. However, the highest CAR was less than 1\%, indicating that the profits might be limited for this trading strategy.

As for the result for China, we found positive and significant CARs following sharp falls in the exchange rate in China, indicating that the momentum strategy may be productive for trading the constituent stocks of the SSE 50 following more than $0.25 \%$, $0.5 \%$, and $0.75 \%$ falls in the exchange rate in a day.

A fall of more than $1 \%$ in the exchange rate did not occur over the data period from 2006 to 2015 in China; as such, there are no results to be shown in Panel D of Table 4. We infer that the low volatility of the CNY stems from the actions of the monetary authority of China.

Similar to the results for the United States and United Kingdom, the CARs are positive following falls of more than $0.5 \%$ and $0.75 \%$ in the exchange rate in China. Furthermore, the CARs in China are slightly higher than those in the United States and United Kingdom, especially for CAR (5). For example, CAR (5) was $1.35 \%$ and $0.77 \%$ following 
Table 4 CARs of diverse sharp falls in exchange rates. We investigate whether these CARs including 1-, 2-, 3-, 4-, and 5-day CARs would be different from 0 if investors take the long positions in the constituent stocks of DJ 30, FTSE 100, and SSE50 as the sharp rises in exchange rates over $0.25 \%, 0.5 \%, 0.75 \%$, and $1 \%$. We also present the statistics of t-tests for these CARs. In addition, $*^{* *}$, and ${ }^{* *}$ represent $10 \%, 5 \%$, and $1 \%$ significance levels, respectively

\begin{tabular}{|c|c|c|c|c|c|c|c|c|c|}
\hline \multirow{3}{*}{$\begin{array}{l}\text { Holding } \\
\text { days }\end{array}$} & \multicolumn{3}{|l|}{ (1) } & \multicolumn{3}{|l|}{$(2)$} & \multicolumn{3}{|l|}{ (3) } \\
\hline & \multicolumn{3}{|l|}{ DJ30 } & \multicolumn{3}{|l|}{ FTSE100 } & \multicolumn{3}{|l|}{ SSE50 } \\
\hline & Returns & \multicolumn{2}{|l|}{ t-test } & Returns & \multicolumn{2}{|l|}{ t-test } & Returns & \multicolumn{2}{|l|}{ t-test } \\
\hline \multicolumn{10}{|c|}{ Panel A: Over $0.25 \%$ fall in exchange rates } \\
\hline 1 & $0.03 \%$ & 2.951 & $* * *$ & $0.08 \%$ & 8.069 & $* * *$ & $0.07 \%$ & 1.163 & \\
\hline 2 & $0.08 \%$ & 5.084 & $* * *$ & $0.17 \%$ & 11.902 & $* * *$ & $0.25 \%$ & 2.748 & *** \\
\hline 3 & $0.13 \%$ & 6.954 & $* * *$ & $0.29 \%$ & 16.725 & $* * *$ & $0.13 \%$ & 1.130 & \\
\hline 4 & $0.18 \%$ & 8.588 & $* * *$ & $0.34 \%$ & 17.394 & $* * *$ & $0.31 \%$ & 2.434 & $* *$ \\
\hline 5 & $0.23 \%$ & 9.988 & $* * *$ & $0.43 \%$ & 18.945 & $* * *$ & $0.35 \%$ & 2.434 & $* *$ \\
\hline \multicolumn{10}{|c|}{ Panel B: Over $0.5 \%$ fall in exchange rates } \\
\hline 1 & $0.03 \%$ & 1.652 & * & $0.06 \%$ & 4.154 & $* * *$ & $-0.27 \%$ & -1.580 & \\
\hline 2 & $0.11 \%$ & 4.479 & $* * *$ & $0.15 \%$ & 7.228 & $* * *$ & $-0.38 \%$ & -1.505 & \\
\hline 3 & $0.15 \%$ & 4.914 & $* * *$ & $0.30 \%$ & 11.989 & $* * *$ & $-0.01 \%$ & -0.026 & \\
\hline 4 & $0.23 \%$ & 6.642 & $* * *$ & $0.39 \%$ & 13.624 & $* * *$ & $0.52 \%$ & 1.460 & \\
\hline 5 & $0.30 \%$ & 7.734 & $* * *$ & $0.51 \%$ & 15.257 & $* * *$ & $1.35 \%$ & 3.268 & *** \\
\hline \multicolumn{10}{|c|}{ Panel C: Over $0.75 \%$ fall in exchange rates } \\
\hline 1 & $-0.01 \%$ & -0.310 & & $0.09 \%$ & 3.984 & $* * *$ & $-0.42 \%$ & -1.419 & \\
\hline 2 & $0.15 \%$ & 3.758 & $* * *$ & $0.18 \%$ & 5.614 & $* * *$ & $-1.04 \%$ & -2.194 & ** \\
\hline 3 & $0.16 \%$ & 3.220 & $* * *$ & $0.34 \%$ & 8.378 & $* * *$ & $-0.65 \%$ & -1.260 & \\
\hline 4 & $0.26 \%$ & 4.730 & $* * *$ & $0.44 \%$ & 9.140 & $* * *$ & $-0.14 \%$ & -0.254 & \\
\hline 5 & $0.34 \%$ & 5.464 & $* * *$ & $0.60 \%$ & 10.649 & $* * *$ & $0.77 \%$ & 1.227 & \\
\hline \multicolumn{10}{|c|}{ Panel D: Over $1 \%$ fall in exchange rates } \\
\hline 1 & $0.03 \%$ & 0.657 & & $0.09 \%$ & 2.444 & $* *$ & - & - & \\
\hline 2 & $0.29 \%$ & 4.342 & $* * *$ & $0.32 \%$ & 6.290 & $* * *$ & - & - & \\
\hline 3 & $0.31 \%$ & 3.748 & $* * *$ & $0.51 \%$ & 8.152 & $* * *$ & - & - & \\
\hline 4 & $0.38 \%$ & 4.168 & $* * *$ & $0.69 \%$ & 9.033 & $* * *$ & - & - & \\
\hline 5 & $0.40 \%$ & 3.842 & $* * *$ & $0.87 \%$ & 9.604 & $* * *$ & - & - & \\
\hline
\end{tabular}

$0.5 \%$ and $0.75 \%$ falls in the exchange rate for China, which are higher than those shown for the United States and United Kingdom.

As all of the CARs are positive without exception for the United States and United Kingdom, the results indicate that taking a long position would be appropriate for trading the constituent stocks of the United States and United Kingdom following both sharp currency appreciation and depreciation for these two countries. However, the CARs are all less than $1 \%$.

For China, significantly negative CARs were observed after a sharp depreciation of the CNY. CAR (5) was $-5.01 \%$ for the constituent stocks of the SSE 50 after a $1 \%$ drop in the CNY in a day, whereas it was $1.35 \%$ after a $0.5 \%$ appreciation in the CNY. These CAR results are more volatile than those for the United States and United Kingdom. In summary, for China, share prices increased after a sharp appreciation in the $\mathrm{CNY}$, and they weakened after a sharp depreciation in the 
CNY. We infer that the SSE 50 in not as mature as the DJ 30 and FTSE 100, resulting in market inefficiency.

\section{Conclusions}

We hypothesized that heightened sentiments of investors' following sharp exchange rate movements in a day would impact the movements in the respective stock markets. We examined whether investors would realize profits in trading the constituent stocks of the DJ 30, FTSE 100, and SSE 50 right after sharp appreciations or depreciations of over $0.25 \%, 0.5 \%, 0.75 \%$, and $1 \%$ rises in the respective exchange rates in the countries. We regard that such currency movements have informational value for market participants.

Our hypotheses are likely connected to market efficiency or inefficiency. Sharp changes in exchange rates might cause herd behaviors and overreactions among market participants. The theories of behavioral finance are applicable to this situation. Our results can help guide investing and trading strategies.

By studying the constituent stocks of the DJ 30, FTSE 100, and SSE 50, we found that the prices of the stocks in those indexes rose following sharp appreciation and depreciation in the USDX and GBP/USD. In the case of China, although the CNY is less volatile than the other two currencies, the share prices are more volatile than the other two markets. CAR (5) was $-5.01 \%$ for trading the constituent stocks of the SSE 50 after a $1 \%$ sharp depreciation in the CNY, whereas it was $1.35 \%$ after a $0.5 \%$ sharp appreciation in the CNY.

Our study adds to the existing literature in several ways. First, to our knowledge, whether market participants can beat the market following sharp exchange rate movements is seldom explored in previous studies. Second, our results can help devise investing strategies triggered by sharp currency movements. We used the constituent stocks of the DJ 30, FTSE100, and SSE 50, since investors are able to trade them instead of the index spots.

There are two implications of our study: First, investors might be able to outperform the market if they are able to track sharp rises and falls in these exchange rates. Second, our empirical results provide valuable information for investors for trading in such situations.

In addition to the event study approach, several other approaches are worthy of further investigation. For example, Kou et al. (2012) proposed an approach based on Spearman's rank correlation to resolve disagreements among multiple criteria decisionmaking (MCDM) methods. Kou et al. (2014a, b) further demonstrated the effectiveness of MCDM methods in evaluating clustering algorithms for financial risk analysis. By proposing a cosine maximization method for the priority vector derivation in the Analytic Hierarchy Process (AHP), Kou and Lin (2014) demonstrated that cosine maximization is more flexible and efficient than other prioritization methods. They also proposed a Hadamard model to mitigate judgment contradiction and showed that the model enhances data consistency in the decision matrix.

Recently, because AHP has been widely adopted for group decision-making (GDM), Lin et al. (2020) proposed aggregation of the nearest consistent matrices with the acceptable consensus in AHP-GDM. Zhang et al. (2019) also proposed consensus models involving both the consensus degree and cost in GDM and showed the usability of the models in real-world contexts. Employing these approaches would be beneficial for further research in this area. 


\section{Appendix}

In addition to exploring whether investors are able to beat the market after sharp movements in exchanges rates, we explored whether market participants are able to beat the market following high or low levels of VIX (a volatility index) at either the high $90 \%, 95 \%$, and $97.5 \%$ quantiles or the low $2.5 \%, 5 \%$, and $10 \%$ quantiles. The results are shown in Tables 5 and 6.

Table 5 shows that the CARs are positive if investors take long positions in trading the constituent stocks of the DJ 30, FTSE 100, and SSE50 following VIX levels in the $90 \%, 95 \%$, and $97.5 \%$ quantiles, indicating that market participants might profit from momentum strategies amid panic sentiments in those stock markets. Buying these constituent stocks in panicked markets might not be a bad strategy, as stocks may perhaps have dropped considerably when the VIX is at a high level.

However, Table 6 shows that the CARs are not the same for taking long positions in the constituent stocks of the DJ 30, FTSE 100, and SSE50 when the VIX levels are in the $10 \%, 5 \%$, and $2.5 \%$ quantiles. CARs are negative for taking long positions on the constituent stocks of the DJ 30, but they are positive for taking short positions on the constituent stocks of the SSE 50. The results indicate that the SSE 50 stock prices could still rise even in the absence of a panicked atmosphere (i.e., low VIX level); however, the results might not be the same for trading the DJ 30 and FTSE 100 stocks in the same circumstances.

Table 5 CARs of VIX located at 90\%, 95\%, and 97.5\% quantiles. We investigate whether these CARs including 1-, 2-, 3-, 4-, and 5-day CARs would be different from 0 if investors take the long positions in the constituent stocks of DJ 30, FTSE 100, and SSE50 as the VIXs located at 90\%, 95\%, and 97.5\% quantile. We also present the statistics of t-tests for these CARs. In addition, ${ }^{*},{ }^{* *}$, and ${ }^{* * *}$ represent $10 \%, 5 \%$, and $1 \%$ significance levels, respectively

\begin{tabular}{|c|c|c|c|c|c|c|c|c|c|}
\hline \multirow{3}{*}{$\begin{array}{l}\text { Holding } \\
\text { days }\end{array}$} & \multicolumn{3}{|l|}{ (1) } & \multicolumn{3}{|l|}{ (2) } & \multicolumn{3}{|l|}{ (3) } \\
\hline & \multicolumn{3}{|l|}{ DJ30 } & \multicolumn{3}{|l|}{ FTSE100 } & \multicolumn{3}{|l|}{ SSE50 } \\
\hline & Returns & \multicolumn{2}{|l|}{ t-test } & Returns & \multicolumn{2}{|l|}{ t-test } & Returns & \multicolumn{2}{|l|}{ t-test } \\
\hline \multicolumn{10}{|c|}{ Panel A: VIX located at 90\% quantile } \\
\hline 1 & $0.18 \%$ & 5.481 & $* * *$ & $0.18 \%$ & 7.136 & $* * *$ & $0.19 \%$ & 6.231 & $* * *$ \\
\hline 2 & $0.34 \%$ & 7.426 & $* * *$ & $0.40 \%$ & 10.877 & $* * *$ & $0.44 \%$ & 10.16 & $* * *$ \\
\hline 3 & $0.52 \%$ & 9.572 & $* * *$ & $0.60 \%$ & 13.421 & $* * *$ & $0.72 \%$ & 13.653 & $* * *$ \\
\hline 4 & $0.66 \%$ & 10.807 & $* * *$ & $0.83 \%$ & 16.049 & $* * *$ & $0.93 \%$ & 15.272 & $* * *$ \\
\hline 5 & $0.81 \%$ & 12.007 & $* * *$ & $1.01 \%$ & 17.537 & $* * *$ & $1.10 \%$ & 16.203 & $* * *$ \\
\hline \multicolumn{10}{|c|}{ Panel B: VIX located at 95\% quantile } \\
\hline 1 & $0.25 \%$ & 4.502 & $* * *$ & $0.19 \%$ & 4.663 & $* * *$ & $0.27 \%$ & 5.643 & $* * *$ \\
\hline 2 & $0.43 \%$ & 5.668 & $* * *$ & $0.38 \%$ & 6.181 & $* * *$ & $0.55 \%$ & 8.23 & $* * *$ \\
\hline 3 & $0.56 \%$ & 6.251 & $* * *$ & $0.56 \%$ & 7.431 & $* * *$ & $0.87 \%$ & 10.588 & $* * *$ \\
\hline 4 & $0.70 \%$ & 6.855 & $* * *$ & $0.75 \%$ & 8.791 & $* * *$ & $1.14 \%$ & 11.924 & $* * *$ \\
\hline 5 & $0.92 \%$ & 8.186 & $* * *$ & $0.93 \%$ & 9.661 & $* * *$ & $1.44 \%$ & 13.428 & $* * *$ \\
\hline \multicolumn{10}{|c|}{ Panel C: VIX located at 97.5\% quantile } \\
\hline 1 & $0.26 \%$ & 2.915 & $* * *$ & $0.12 \%$ & 1.811 & * & $0.21 \%$ & 2.829 & $* * *$ \\
\hline 2 & $0.47 \%$ & 3.872 & $* * *$ & $0.35 \%$ & 3.704 & $* * *$ & $0.46 \%$ & 4.461 & $* * *$ \\
\hline 3 & $0.66 \%$ & 4.535 & $* * *$ & $0.48 \%$ & 4.086 & $* * *$ & $0.71 \%$ & 5.567 & $* * *$ \\
\hline 4 & $0.96 \%$ & 5.999 & $* * *$ & $0.65 \%$ & 4.891 & $* * *$ & $0.77 \%$ & 5.134 & $* * *$ \\
\hline 5 & $1.28 \%$ & 7.582 & $* * *$ & $1.00 \%$ & 6.903 & $* * *$ & $0.98 \%$ & 5.82 & $* * *$ \\
\hline
\end{tabular}


Table 6 CARs of VIX located at 10\%, 5\%, and 2.5\% quantiles. We investigate whether these CARs including 1-, 2-, 3-, 4-, and 5-day CARs would be different from 0 if investors take the long positions in the constituent stocks of DJ 30, FTSE 100, and SSE50 as the VIXs located at 10\%, 5\%, and $2.5 \%$ quantile. We also present the statistics of t-tests for these CARs. In addition, ${ }^{*}$,**, and *** represent $10 \%, 5 \%$, and $1 \%$ significance levels, respectively

\begin{tabular}{|c|c|c|c|c|c|c|c|c|c|}
\hline \multirow{3}{*}{$\begin{array}{l}\text { Holding } \\
\text { days }\end{array}$} & \multicolumn{3}{|l|}{ (1) } & \multicolumn{3}{|l|}{ (2) } & \multicolumn{3}{|l|}{ (3) } \\
\hline & \multicolumn{3}{|l|}{ DJ30 } & \multicolumn{3}{|l|}{ FTSE100 } & \multicolumn{3}{|l|}{ SSE50 } \\
\hline & Returns & \multicolumn{2}{|l|}{ t-test } & Returns & \multicolumn{2}{|l|}{ t-test } & Returns & \multicolumn{2}{|l|}{ t-test } \\
\hline \multicolumn{10}{|c|}{ Panel A: VIX located at $10 \%$ quantile } \\
\hline 1 & $-0.03 \%$ & -2.594 & $* * *$ & $0.06 \%$ & 5.007 & $* * *$ & $0.29 \%$ & 8.211 & $* * *$ \\
\hline 2 & $-0.05 \%$ & -2.801 & $* * *$ & $0.06 \%$ & 3.51 & $* * *$ & $0.46 \%$ & 8.827 & $* * *$ \\
\hline 3 & $-0.05 \%$ & -2.292 & $* *$ & $0.07 \%$ & 3.49 & $* * *$ & $0.63 \%$ & 9.629 & $* * *$ \\
\hline 4 & $-0.08 \%$ & -3.266 & $* * *$ & $0.07 \%$ & 3.355 & $* * *$ & $0.75 \%$ & 9.809 & *** \\
\hline 5 & $-0.10 \%$ & -3.529 & $* * *$ & $0.09 \%$ & 3.509 & $* * *$ & $0.99 \%$ & 11.52 & $* * *$ \\
\hline \multicolumn{10}{|c|}{ Panel B: VIX located at 5\% quantile } \\
\hline 1 & $-0.04 \%$ & -2.25 & $* *$ & $0.06 \%$ & 3.299 & $* * *$ & $0.21 \%$ & 3.632 & $* * *$ \\
\hline 2 & $-0.07 \%$ & -2.844 & $* * *$ & $0.08 \%$ & 3.678 & $* * *$ & $0.37 \%$ & 4.383 & $* * *$ \\
\hline 3 & $-0.09 \%$ & -2.78 & $* * *$ & $0.07 \%$ & 2.857 & $* * *$ & $0.78 \%$ & 7.45 & $* * *$ \\
\hline 4 & $-0.14 \%$ & -3.761 & $* * *$ & $0.08 \%$ & 2.858 & $* * *$ & $1.01 \%$ & 8.306 & $* * *$ \\
\hline 5 & $-0.18 \%$ & -4.384 & $* * *$ & $0.07 \%$ & 2.017 & $* *$ & $1.21 \%$ & 8.747 & $* * *$ \\
\hline \multicolumn{10}{|c|}{ Panel C: VIX located at $2.5 \%$ quantile } \\
\hline 1 & $-0.03 \%$ & -1.006 & & $0.12 \%$ & 6.645 & $* * *$ & $0.26 \%$ & 2.94 & $* * *$ \\
\hline 2 & $-0.15 \%$ & -4.338 & $* * *$ & $0.09 \%$ & 3.878 & $* * *$ & $0.59 \%$ & 4.319 & $* * *$ \\
\hline 3 & $-0.25 \%$ & -5.988 & $* * *$ & $0.05 \%$ & 1.651 & * & $0.99 \%$ & 5.994 & $* * *$ \\
\hline 4 & $-0.33 \%$ & -6.696 & $* * *$ & $-0.03 \%$ & -0.9 & & $1.29 \%$ & 6.88 & $* * *$ \\
\hline 5 & $-0.44 \%$ & -7.882 & $* * *$ & $-0.09 \%$ & -2.357 & $* *$ & $1.57 \%$ & 7.423 & $* * *$ \\
\hline
\end{tabular}

As the sentiments triggered by the occurrence of sharp movements in exchange rates might be different from those triggered by VIX movements, trading the constituent stocks in the two scenarios could lead to different trading performances.

We also examined whether significant CARs were achieved for trading the constituent stocks following bullish or bearish investors' sentiment as measured by the AAII sentiment survey.

The bullish (bearish) investors' sentiments were set as over $40 \%$ bullish (bearish) investors' sentiments and over $50 \%$ bullish (bearish) investors' sentiments as measured by the AAII sentiment survey. As only weekly data are available in the AAII sentiment survey, we employed weekly data instead of daily data. Significant CARs were observed, as shown in Tables 7-8, indicating that investors can beat the SSE 50 by trading the constituents stocks right after bullish or bearish sentiments, except for the case of over $50 \%$ bearish sentiment.

As shown in Table 9, the correlations between over $50 \%$ bullish sentiment and the USDX, GBP/USD, and USD/CNY are higher than those between over $40 \%$ bullish sentiments and the exchange rates. The correlations between over $50 \%$ bearish sentiment and the exchange rates are large, both positive or negative, compared with the correlations between over $40 \%$ bearish sentiment and the exchange rates. These results might provide supplemental evidence for our hypothesized mechanism. 
Table 7 CARs of bullish investors' sentiments aroused. We investigate whether these CARs including 1-, 2-, 3-, 4-, and 5-week CARs would be different from 0 if investors take the long positions in the constituent stocks of DJ 30, FTSE 100, and SSE50 as the bullish investors' sentiments aroused. We also present the statistics of t-tests for these CARs. In addition, ${ }^{*},{ }^{* *}$, and ${ }^{* * *}$ represent $10 \%, 5 \%$, and $1 \%$ significance levels, respectively

\begin{tabular}{|c|c|c|c|c|c|c|c|c|c|}
\hline \multirow{3}{*}{$\begin{array}{l}\text { Holding } \\
\text { days }\end{array}$} & \multicolumn{3}{|l|}{ (1) } & \multicolumn{3}{|l|}{ (2) } & \multicolumn{3}{|l|}{ (3) } \\
\hline & \multicolumn{3}{|l|}{ DJ30 } & \multicolumn{3}{|l|}{ FTSE100 } & \multicolumn{3}{|l|}{ SSE50 } \\
\hline & Returns & \multicolumn{2}{|l|}{ t-test } & Returns & \multicolumn{2}{|l|}{ t-test } & Returns & \multicolumn{2}{|l|}{ t-test } \\
\hline \multicolumn{10}{|c|}{ Panel A: Over $40 \%$ bullish investors' sentiments measured by AAll sentiment survey } \\
\hline 1 & $0.21 \%$ & 5.890 & $* * *$ & $0.21 \%$ & 7.497 & *** & $0.68 \%$ & 8.454 & *** \\
\hline 2 & $0.38 \%$ & 7.563 & *** & $0.47 \%$ & 11.993 & $* * *$ & $1.39 \%$ & 12.106 & $* * *$ \\
\hline 3 & $0.57 \%$ & 9.552 & $* * *$ & $0.71 \%$ & 15.496 & $* * *$ & $2.05 \%$ & 14.165 & $* * *$ \\
\hline 4 & $0.73 \%$ & 10.666 & $* * *$ & $0.83 \%$ & 15.383 & $* * *$ & $2.85 \%$ & 16.586 & $* * *$ \\
\hline 5 & $0.82 \%$ & 10.466 & $* * *$ & $0.95 \%$ & 15.828 & $* * *$ & $3.67 \%$ & 18.948 & $* * *$ \\
\hline \multicolumn{10}{|c|}{ Panel B: Over 50\% bullish investors' sentiments measured by AAll sentiment survey } \\
\hline 1 & $0.06 \%$ & 0.713 & & $0.20 \%$ & 3.383 & $* * *$ & $1.23 \%$ & 5.694 & $* * *$ \\
\hline 2 & $0.13 \%$ & 1.186 & & $0.52 \%$ & 6.255 & *** & $1.71 \%$ & 5.582 & $* * *$ \\
\hline 3 & $0.45 \%$ & 3.342 & $* * *$ & $0.98 \%$ & 9.608 & $* * *$ & $2.83 \%$ & 6.677 & $* * *$ \\
\hline 4 & $0.51 \%$ & 3.299 & $* * *$ & $1.10 \%$ & 9.050 & $* * *$ & $3.90 \%$ & 7.764 & $* * *$ \\
\hline 5 & $0.60 \%$ & 3.345 & $* * *$ & $1.06 \%$ & 7.405 & $* * *$ & $4.25 \%$ & 7.500 & $* * *$ \\
\hline
\end{tabular}

Table 8 CARs of bearish investors' sentiments aroused. We investigate whether these CARs including 1-, 2-, 3-, 4-, and 5-week CARs would be different from 0 if investors take the long positions in the constituent stocks of DJ 30, FTSE 100, and SSE50 as the bearish investors' sentiments aroused. We also present the statistics of t-tests for these CARs. In addition, ${ }^{*},{ }^{* *}$, and ${ }^{* * *}$ represent $10 \%, 5 \%$, and $1 \%$ significance levels, respectively

\begin{tabular}{|c|c|c|c|c|c|c|c|c|c|}
\hline \multirow{3}{*}{$\begin{array}{l}\text { Holding } \\
\text { days }\end{array}$} & \multicolumn{3}{|l|}{$(1)$} & \multicolumn{3}{|l|}{ (2) } & \multicolumn{3}{|l|}{ (3) } \\
\hline & \multicolumn{3}{|l|}{ DJ30 } & \multicolumn{3}{|l|}{ FTSE100 } & \multicolumn{3}{|l|}{ SSE50 } \\
\hline & Returns & t-test & & Returns & t-test & & Returns & t-test & \\
\hline \multicolumn{10}{|c|}{ Panel A: Over 40\% bearish investors' sentiments measured by AAll sentiment survey } \\
\hline 1 & $0.21 \%$ & 3.065 & *** & $0.33 \%$ & 6.357 & *** & $0.59 \%$ & 5.110 & $* * *$ \\
\hline 2 & $0.39 \%$ & 4.347 & $* * *$ & $0.48 \%$ & 6.808 & $* * *$ & $1.12 \%$ & 6.822 & $* * *$ \\
\hline 3 & $0.67 \%$ & 6.013 & $* * *$ & $0.77 \%$ & 8.999 & $* * *$ & $1.37 \%$ & 6.767 & $* * *$ \\
\hline 4 & $0.98 \%$ & 7.676 & $* * *$ & $1.22 \%$ & 12.595 & $* * *$ & $1.47 \%$ & 6.273 & $* * *$ \\
\hline 5 & $1.27 \%$ & 9.084 & $* * *$ & $1.56 \%$ & 14.522 & $* * *$ & $1.90 \%$ & 7.175 & $* * *$ \\
\hline
\end{tabular}

Panel B: Over 50\% bearish investors' sentiments measured by AAll sentiment survey

\begin{tabular}{lllllllll}
1 & $0.19 \%$ & 1.004 & & $0.13 \%$ & 0.946 & & $-0.16 \%$ & -0.539 \\
2 & $0.50 \%$ & 2.150 & $* *$ & $-0.09 \%$ & -0.474 & & $0.29 \%$ & 0.718 \\
3 & $0.76 \%$ & 2.583 & $* * *$ & $0.53 \%$ & 2.272 & $* *$ & $-0.57 \%$ & -1.190 \\
4 & $1.28 \%$ & 3.789 & $* * *$ & $1.43 \%$ & 5.392 & $* * *$ & $-0.55 \%$ & -0.998 \\
5 & $1.51 \%$ & 4.161 & $* * *$ & $1.60 \%$ & 5.323 & $* * *$ & $-0.81 \%$ & -1.330 \\
\hline
\end{tabular}


Table 9 Correlation Matrices

\begin{tabular}{|c|c|c|c|c|}
\hline \multicolumn{5}{|c|}{ Panel A Correlation Matrix in terms of Bullish 50 and currencies } \\
\hline & Bullish50 & USDX & GBP/USD & USD/CNY \\
\hline Bullish50 & 1.000 & & & \\
\hline USDX & 0.055 & 1.000 & & \\
\hline GBP/USD & 0.056 & 0.147 & 1.000 & \\
\hline USD/CNY & 0.084 & 0.317 & 0.789 & 1.000 \\
\hline \multicolumn{5}{|c|}{ Panel B Correlation Matrix in terms of Bullish 40 and currencies } \\
\hline & Bullish40 & USDX & GBP/USD & USD/CNY \\
\hline Bullish40 & 1.000 & & & \\
\hline USDX & 0.021 & 1.000 & & \\
\hline GBP/USD & 0.002 & 0.098 & 1.000 & \\
\hline USD/CNY & 0.032 & 0.360 & 0.749 & 1.000 \\
\hline \multicolumn{5}{|c|}{ Panel C Correlation Matrix in terms of Bearish 50 and currencies } \\
\hline & Bearish50 & USDX & GBP/USD & USD/CNY \\
\hline Bearish50 & 1.000 & & & \\
\hline USDX & 0.323 & 1.000 & & \\
\hline GBP/USD & -0.291 & -0.785 & 1.000 & \\
\hline USD/CNY & -0.169 & 0.045 & 0.493 & 1.000 \\
\hline \multicolumn{5}{|c|}{ Panel D Correlation Matrix in terms of Bearish 40 and currencies } \\
\hline & Bearish40 & USDX & GBP/USD & USD/CNY \\
\hline Bearish40 & 1.000 & & & \\
\hline USDX & 0.003 & 1.000 & & \\
\hline GBP/USD & 0.134 & -0.283 & 1.000 & \\
\hline USD/CNY & 0.054 & 0.396 & 0.640 & 1.000 \\
\hline
\end{tabular}

\section{Authors' contributions}

Prof. Huang collected and went through the initial screening of the data employed in this study. Prof. Ni and Prof. Day conducted the empirical results for this paper. Prof. Huang and Prof. Ni surveyed the relevant literature and interpreted empirical results. All of us read, finalized and approved the final manuscript.

Funding

We hereby confirm that there are no funds supported for this research paper/study.

\section{Availability of data and materials}

The datasets used and/or analyzed during the current study are available from the corresponding author on reasonable request at hpy315315@gmail.com.

\section{Competing interests}

The authors declare that they have no competing interests.

\section{Author details}

${ }^{1}$ Department of Management Sciences, Tamkang University, New Taipei City, Taiwan. ${ }^{2}$ Graduate Institute of Information Management, National Taipei University, New Taipei City, Taiwan. ${ }^{3}$ Department of International Business, Soochow University, No.56, Sec. 1, Kueiyang St., Taipei City 100, Taiwan.

Received: 8 March 2019 Accepted: 7 August 2020

Published online: 27 September 2020

\section{References}

Aggarwal R (1981) Exchange rates and stock prices: a study of the US capital markets under floating exchange rates. Akron Bus Econ Rev 12(4):7-12

Ahern KR (2009) Sample selection and event study estimation. J Empir Financ 16(3):466-482

Ajayi RA, Friedman J, Mehdian SM (1999) On the relationship between stock returns and exchange rates: tests of granger causality. Global Financ J 9(2):241-251

Ajayi RA, Mougoue M (1996) On the dynamic relation between stock prices and exchange rates. J Financ Research 19(2):193-207 
Antoniou A, Koutmos G, Pericli A (2005) Index futures and positive feedback trading: evidence from major stock exchanges. J Empir Financ 12(2):219-238

Bahmani-oskooee M, Sohrabian A (1992) Stock price and the effective exchange rate of the dollar. Appl econ, 24: 459-464 Bahmani-Oskooee M, Saha S (2017) Asymmetric response of the US-India trade balance to exchange rate changes: Evidence from 68 industries. World Economy 40(10):2226-2254

Baker M, Wurgler J (2006) Investor sentiment and the cross-section of stock returns. J Financ 61(4):1645-1680

Balcilar M, Demirer R, Hammoudeh S (2013) Investor herds and regime-switching: evidence from gulf Arab stock markets. J Int Financ Markets I 23:295-321

Barney JB (1988) Returns to bidding firms in mergers and acquisitions: reconsidering the relatedness hypothesis. Strategic Manag J 9(S1):71-78

Bartov E, Bodnar GM (1994) Firm valuation, earnings expectations, \& the exchange-rate exposure effect. J Financ 49:1755-1785

Basher SA, Haug AA, Sadorsky P (2012) Oil prices, exchange rates and emerging stock markets. Energy Econ 34(1):227-240

Bekiros S, Jlassi M, Lucey B, Naoui K, Uddin GS (2017) Herding behavior, market sentiment and volatility: will the bubble resume? N Am J Econ Financ 42:107-131

Bessembinder H, Chan K (1995) The profitability of technical trading rules in the Asian stock markets. Pacific-Basin Financ J 3(2-3): 257-284

Brock W, Lakonishok J, LeBaron B (1992) Simple technical trading rules and the stochastic properties of stock returns. J Financ 47(5): 1731-1764

Brown NC, Wei KD, Wermers R (2013) Analyst recommendations, mutual fund herding, \& overreaction in stock prices. Manag Sci 60(1):1-20

Calvo GA, Leiderman L, Reinhart CM (1993) Capital inflows and real exchange rate appreciation in Latin America: the role of external factors. Staff Papers 40(1):108-151

Calvo GA, Leiderman L, Reinhart CM (1996) Inflows of capital to developing countries in the 1990s. J Econ Perspect 10(2):123-139

Chalmers J, Kaul A, Phillips B (2013) The wisdom of crowds: mutual fund investors' aggregate asset allocation decisions. J Bank Financ 37(9):3318-3333

Charest G (1978) Dividend information, stock returns and market efficiency-II. J Financ Economics 6(2-3):297-330

Chiang TC, Yang SY (2003) Foreign exchange risk premiums and time-varying equity market risks. Int J Risk Assess Manage 4(4): 310-331

Chiang TC, Zheng D (2010) An empirical analysis of herd behavior in global stock markets. J Bank Financ 34(8):1911-1921

Chinn MD (2006) A primer on real effective exchange rates: determinants, overvaluation, trade flows and competitive devaluation. Open Econ Rev 17(1):115-143

Chopra N, Lakonishok J, Ritter JR (1992) Measuring abnormal performance - do stocks overreact. J Financ Econ 31(2):235-268

Chuang WI, Lee BS (2006) An empirical evaluation of the overconfidence hypothesis. J Bank Financ 30(9):2489-2515

Corsetti G, Pesenti P, Roubini N, Tille C (2000) Competitive devaluations: toward a welfare-based approach. J Int Econ 51(1): 217-241

Da Z, Engelberg J, Gao P (2015) The sum of all FEARS investor sentiment and asset prices. Rev Financ Stud 28(1):1-32

Daniel K, Hirshleifer D, Subrahmanyam A (1998) Investor psychology and security market under-and overreactions. J Financ 53(6):1839-1885

De Haan L, Kakes J (2011) Momentum or contrarian investment strategies: evidence from Dutch institutional investors. J Bank Financ 35(9):2245-2251

Debondt WFM, Thaler RH (1985) Does the stock-market overreact. J Financ 40(3):793-805

Debondt WFM, Thaler RH (1987) Further evidence on investor overreaction and stock-market seasonality. J Financ 42(3):557-581

Dennis PJ, Strickland D (2002) Who blinks in volatile markets, individuals or institutions? J Financ 57(5):1923-1949

Dergiades T (2012) Do investors' sentiment dynamics affect stock returns? Evidence from the US economy. Econ Lett 116(3):404-407

Donnelly R, Sheehy E (1996) The share price reaction of UK exporters to exchange rate movements: an empirical study. J Int Bus Stud 27(1):157-165

Dornbusch R (1987) Exchange rates and prices. American Econ Rev:93-106

Economou F, Kostakis A, Philippas N (2011) Cross-country effects in herding behaviour: evidence from four south European markets. J Int Financ Markets I 21(3):443-460

Fama EF (1965) The behavior of stock-market prices. J Bus 38(1):34-105

Fama EF (1991) Efficient capital markets: II. J Finance 46(5):1575-1617

Fama EF (1998) Market efficiency, long-term returns, \& behavioral finance. J Financ Econ 49(3):283-306

Fang W, Lai Y, Miller SM (2006) Export promotion through exchange rate changes: exchange rate depreciation or stabilization? Southern Econ J:611-626

Firth M (1996) Dividend changes, abnormal returns, and intra-Industry firm valuations. J Financ and Quantitative Analysis 31(2):189-211

Frey S, Herbst P. Walter A (2014) Measuring mutual fund herding-a structural approach. J Inte Financ Markets | 32:219-239

Grammig J, Melvin M, Schlag C (2005) Internationally cross-listed stock prices during overlapping trading hours: price discovery and exchange rate effects. J Empirical Finance 12(1):139-164

Griffin JM, Harris JH, Topaloglu S (2003) The dynamics of institutional and individual trading. J Financ 58(6):2285-2320

Griffin JM, Stulz RM (2001) International competition and exchange rate shocks: a cross-country industry analysis of stock returns. Rev Financ Stud 14(1):215-241

Grinblatt M, Titman S, Wermers R (1995) Momentum investment strategies, portfolio performance, \& herding: a study of mutual fund behavior. American Econ Rev:1088-1105

Gruber JW, Kamin SB (2007) Explaining the global pattern of current account imbalances. J Int Money Finance 26(4):500-522 Hackbarth D, Morellec E (2008) Stock returns in mergers and acquisitions. J Finance 63(3):1213-1252

Hamao Y, Masulis RW, Ng V (1990) Correlations in price changes and volatility across international stock markets. Rev Financ Stud 3(2):281-308

Heiden S, Klein C, Zwergel B (2013) Beyond fundamentals: investor sentiment and exchange rate forecasting. European Financ Manag 19(3):558-578 
Huang D, Jiang F, Tu J, Zhou G (2014) Investor sentiment aligned: a powerful predictor of stock returns. Rev Financ Stud 28(3):791-837

Huang P, Ni Y (2017) Board structure and stock price informativeness in terms of moving average rules. Quarterly Rev Econ Financ 63:161-169

Jorion P (1990) The exchange-rate exposure of US multinationals. J Bus:331-345

Kahneman D, Tversky A (1979) Prospect theory: an analysis of decision under risk. Econometrica. J Econometric Society:263-291

Karolyi GA (1995) A multivariate GARCH model of international transmissions of stock returns and volatility: the case of the United States and Canada. J Bus Econ Statistics 13(1):11-25

King MA, Wadhwani S (1990) Transmission of volatility between stock markets. Rev Financ Stud 3(1):5-33

Kou G, Ergu D, Shang J (2014a) Enhancing data consistency in decision matrix: adapting Hadamard model to mitigate judgment contradiction. Eur J Operational Res 236(1):261-271

Kou G, Lin C (2014) A cosine maximization method for the priority vector derivation in AHP. Eur J Operational Res 235(1):225-232

Kou G, Lu Y, Peng Y, Shi Y (2012) Evaluation of classification algorithms using MCDM and rank correlation. Int J Inf Technol Decision Making 11(01):197-225

Kou G, Peng Y, Wang G (2014b) Evaluation of clustering algorithms for financial risk analysis using MCDM methods. Inf Sci 275:1-12

Koutmos G, Saidi R (2001) Positive feedback trading in emerging capital markets. Appl Financ Econ 11(3):291-297

Kremer S, Nautz D (2013) Causes and consequences of short-term institutional herding. J Bank Financ 37(5):1676-1686

Kumar A, Page JK, Spalt OG (2013) Investor sentiment and return comovements: evidence from stock splits and headquarters changes. Rev Financ 17(3):921-953

Kurov A (2008) Investor sentiment, trading behavior and informational efficiency in index futures markets. Financ Rev 43(1):107-127

Lakonishok J, Shleifer A, Vishny RW (1992) The impact of institutional trading on stock prices. J Financ Econ 32(1):23-43

Liao TL, Huang CJ, Wu CY (2011) Do fund managers herd to counter investor sentiment? J Bus Research 64(2):207-212

Lie E (2005) Operating performance following open market share repurchase announcements. J Acc Econ 39(3):411-436

Lin C, Kou G, Peng Y, Alsaadi FE (2020) Aggregation of the nearest consistency matrices with the acceptable consensus in AHP-GDM. Ann Operations Res:1-17

Lin CH (2011) Exchange rate exposure in the Asian emerging markets. J Multinational Financ Manag 21(4):224-238

Lin W, Engle R, Ito T (1994) Do bulls and bears move across borders? International transmission of stock returns and volatility as the world turns. Rev Financ Stud 7:507-537

Malin M, Bornholt G (2013) Long-term return reversal: evidence from international market indices. J Int Financ Mark I 25:1-17

Malkiel BG, Fama EF (1970) Efficient capital markets: A review of theory and empirical work. J Financ 25: 383-417

Marshall BR, Young MR, Rose LC (2006) Candlestick technical trading strategies: can they create value for investors? J Bank Financ 30(8):2303-2323

Mendel B, Shleifer A (2012) Chasing noise. J Financ Econ 104(2):303-320

Menkhoff L, Sarno L, Schmeling M, Schrimpf A (2012) Carry trades and global foreign exchange volatility. J Financ 67(2):681-718

Netter JM, Mitchell ML (1989) Stock-repurchase announcements and insider transactions after the October 1987 stock market crash. Financ Manag 18(3):84-96

Nguyen P (2016) The role of the seller's stock performance in the market reaction to divestiture announcements. J Econ Financ 40(1):19-40

Ni Y, Liao YC, Huang P (2015) MA trading rules, herding behaviors, \& stock market overreaction. Int Rev Econ Financ 39:253-265

Nofsinger JR, Sias RW (1999) Herding and feedback trading by institutional and individual investors. J Financ 54(6):2263-2295

Pan MS, Fok RC, Liu YA (2007a) Dynamic linkages between exchange rates and stock prices: evidence from east Asian markets. Int Rev Econ Financ 16:503-520

Pan MS, Fok RCW, Liu YA (2007b) Dynamic linkages between exchange rates and stock prices: evidence from east Asian markets. Int Rev Econ Finance 16(4):503-520

Raddatz C, Schmukler SL (2013) Deconstructing herding: evidence from pension fund investment behavior. J Financ Serv Res 43(1):99-126

Ramasamy B, Yeung MC (2002) The relationship between exchange rates and stock prices: Implications for capital controls. Asia Pacific J Econ Bus 6(2):46-60

Ramiah V, Xu X, Moosa IA (2015) Neoclassical finance, behavioral finance and noise traders: a review and assessment of the literature. Int Rev Financ Anal 41:89-100

Rehman M (2013) Investor sentiments and exchange rate volatility. Bus Rev 8(1):123-134

Scharfstein DS, Stein JC (1990) Herd behavior and investment. American Econ Rev:465-479

Schmeling M (2009) Investor sentiment and stock returns: some international evidence. J Empir Financ 16(3):394-408

Schwert GW (1990) Stock returns and real activity: A century of evidence. J Financ 45(4):1237-1257

Schwert GW (2003) Anomalies and market efficiency. Handbook of the Econonics of Finance 1:939-974

Sias RW (2004) Institutional herding. Rev Financ Stud 17(1):165-206

Theodosiou P, Lee U (1993) Mean and volatility spillovers across major national stock markets: further empirical evidence. J Financ Res 16:337-350

Wang C (2002) Information, trading demand, \& futures price volatility. Financ Rev 37(2):295-315

Wu M, Huang P, Ni Y (2017a) Investing strategies as continuous rising (falling) share prices released. J Econ Financ 41(4):763-773

Wu M, Huang P, Ni Y (2017b) Capital liberalization and various financial markets: evidence from Taiwan. Q Rev Econ Financ 66:265-274

Zhang H, Kou G, Peng Y (2019) Soft consensus cost models for group decision making and economic interpretations. Eur J Operational Res 277(3):964-980

Zheng D, Li H, Zhu X (2015) Herding behavior in institutional investors: evidence from China's stock market. J Multinational Financ Manag 32:59-76

Zia U, Mahmood Z (2013) Exchange rate depreciation and export price competitiveness: the case of Pakistani manufacturing industries. J Asia Pac Econ 18(4):529-542

\section{Publisher's Note}

Springer Nature remains neutral with regard to jurisdictional claims in published maps and institutional affiliations. 